\title{
Bataknese Dalihan Na Tolu Culture System as a Learning Model of French Production Orale Skill
}

\author{
Marice $^{1^{*}}$, Isda Pramuniati ${ }^{2}$, Jubliana Sitompul ${ }^{3}$ \\ 1,2,3Universitas Negeri Medan, Indonesia \\ *marice@unimed.ac.id
}

\begin{abstract}
This study aims to produce a learning model of Production Orale (Speaking Skills) of French level B1 based on the local Batak culture of the Dalihan Na Tolu system with the theme Exprimer des opinions (giving opinions). This research and development with Plomp development model through four phases. The research subjects were 20 of $5^{\text {th }}$ semester students of FBS Unimed French education study programs. Research and development results are obtained through material expert validation, media validation and language validation. The practicality of the learning model is obtained from the assessment of validators and questionnaires to students and the effectiveness of the learning model is obtained from the results of student learning after applying the French speaking learning model based on Dalihan Na Tolu. The results from the responses of students in the category of very practical with an average score of $89.5 \%$, the pre-test and post-test when learning with the blended learning model based on local culture of students before and after using the learning model local Batak culture based on the Dalihan na tolu systems is effective with an average student final grade of 80 in the good category.
\end{abstract}

Keywords: model, speaking, French, local culture, dalihan na tolu

\section{Introduction}

French is a foreign language taught in educational institutions in Indonesia. French learning emphasizes four language skills, namely listening, speaking, reading and writing skills. Speaking skills or Production Orale (PO) is one of the four language skills that must be mastered by French language learners in the FBS Unimed French Language Education Study Program, because speaking skills are a means of expressing the contents of the mind through verbal speech. Speaking is an oral language process expressing thoughts and feelings, reflecting on experiences, and sharing information. If someone has good speaking skills, he will gain social benefits (social interaction activities of individuals) and professional benefits (use of language to make questions, convey facts and knowledge, explain, and describe) [1].

Based on observations of 2017 school year students at the FBS Unimed French Language Education Study Program, only 5 students out of 20 students were active while learning to speak while other students were more silent and less inclined to speak when asked to answer questions in simple French. Students feel difficulties when they want to express ideas, ideas and feelings; difficult pronunciation of French words or sentences with good pronunciation; difficulty in constructing correct simple sentence structures. Error constructing sentences in speaking is shown in the following table. 
Table 1. Error constructing sentences in speaking

\begin{tabular}{ll} 
Error Construction of Sentences in speaking & Correct Construction of Sentences \\
\hline *Elle va à la campus & Elle va au campus 'She goes to campuss' \\
*Je se lave & Je me lave 'I take a bath' \\
*Il y aura beau temps & Il fera beau temps. 'The weather will be sunny' \\
\hline
\end{tabular}

In addition, from the results of the Production Orale (speaking) on examination competency test for semester 5 students in 2017 using the assessment of the standard French language test B1 level DELF (Diplome d'Etudes de la Langue Française) namely the assessment of French language skills in European systems for all learners French in the world, $70 \%$ of students score less than 60 (bad category), $20 \%$ of students score above 80 (good category), and $10 \%$ of students score above 90 (very good category).

Mastery of good speaking skills will deliver someone as an intelligent, creative and communicative individual. The problem is that not all students of French Language Study Program at FBS Unimed French Language Education have good speaking skills and even tend to not have motivation in learning. Whereas learning French speaking skills has been attempted with a variety of techniques, for example with the jeux de rôle (role playing) technique or the jeu de créativité (creative play) technique, etc. In addition, the learning model provided in learning to speak French is through a communicative approach. However, the learning model does not seem to have produced a maximum value in the B1 DELF level category. Therefore, it is necessary to find a solution to improve students' speaking skills in French, which is in the form of a study on the development of Blended learning models based on local Batak culture in a foreign and expected system that is expected to improve the competence and learning outcomes of students speaking.

Based on the problems above related to the $5^{\text {th }}$ semester students 'speaking skills, a research was conducted to develop a blended learning model to improve French students' speaking skills. This development research really needs to be carried out as an effort to provide a solution to the problem of speaking skills of French students. It is expected that through the development of effective, interesting, and efficient French speaking (speaking) blended learning models, improvement in French speaking skills can be realized. The learning model is a specific approach in teaching, which in this case will be used as a blended learning model by integrating elements of the Bataknese culture of Dalihan Na Tolu which is one of the local wisdoms in North Sumatra.

The term Dalihan Na Tolu which is a Batak traditional philosophy that has been for hundreds of years, has a literal meaning of a three-legged stove made of stone which illustrates the 3 important positions of every Batak person in his community. The existence of this community consists of 1) the hula-hula or tulang (uncle), 2) the side of a clan called dongan tubu and 3) the sister called boru plus bere and ibebere (nieces and nephews). The use of the stove system with three legs can be seen when the Batak people hold an event such as a wedding, birth, or death and other celebrations, the implementation of which must be discussed first by involving the three parties. In speaking learning, this system is used by dividing students into groups as a picture of a transitional na tolu. 
Speaking learning activities (PO) by integrating dalihan na tolu's transitional system is to find solutions to a problem in the group that must be discussed and decided through mutual agreement. Among these three elements the problem is always expressed or raised by the body of Dongan Tubu. However, the one who is always given the opportunity to give an opinion at the beginning of a conversation in a discussion is boru. The results of opinions, suggestions, inputs from the boru party are further discussed by Dongan Tubu to obtain mutual agreement, and the last party to provide input and advice is hula. Each party in the group is led by a competent spokesperson, so for the Boru party group played by students whose abilities are below average led by a spokesperson whose abilities are above average, and the Dongan Body is a student whose abilities are being led by a spokesperson whose abilities are also above average, and the hula is a group of students whose abilities are above average, led by a highly competent spokesperson. This means that any discussion that requires broader insight, the hula-hula who will provide solutions to problems that arise to members of the group dongan tubu and boru and bere / ibebere groups.

Learning through the Blended Learning Model is meaningful as a learning pattern that contains elements of mixing, or combining one learning pattern with another learning pattern. In connection with the elements of local culture that are integrated into the Blended learning model based on the Dalihan na Tolu Batak culture studied based on recent study that the learning strategy by promoting culture-based education (folklore culture) needs to be developed in schools, because it is considered to motivate students to learn more actively to provide added value and positive for him [2].

Learning models are conceptual frameworks that describe systematic procedures in organizing learning experiences to achieve learning goals. It is not new to the education community that the teaching and learning process in the classroom requires an appropriate approach and learning model so that pleasant learning conditions for learners can be created so that the material can be conveyed effectively and efficiently with learning objectives that are expected to be achieved optimally. Learners in the era of Information and Communication Technology (ICT) are students who were born and developed in the digital age and are classified as millennial generation. The influence of IT today is very big, technology is something that students want to master. The use of internet media, cell phones and sending messages via SMS has become the daily consumption of people both in cities and villages to convey information to each other. The students already know and use social media Facebook, Line, Instagram, WhatsApp, Twitter, and others that illustrate that students are now very technologically literate globally throughout the world.

Various models of approaches are used in learning, one of which is the blended learning model. The term etymologically blended learning consists of two words namely blended which means mixture and learning which means learning. One of the latest educational issues in the development of globalization and technology is Blended learning. Blended learning is a model that can be applied precisely and involves students actively associated with Information Technology (IT).

Mixed are the two main elements, namely learning in the classroom (classroom lesson) with outside the classroom (online learning). Blended learning model has 4 different concepts, namely: a) Blended learning is learning that combines or combines various web-based technologies, to achieve educational goals, b) Blended learning is a combination of various learning approaches (such as behaviorism, constructivism, cognitivism) to produce an optimal learning achievement with or without learning technology, c) Blended learning is also a combination of many learning technology formats, such as video tapes, CD-ROMs, web-based 
training, films with face-to-face learning, d) Blended learning combines learning technology with actual work task orders to create a good influence on learning and work [3].

General speaking can be interpreted as a delivery of intent (ideas, thoughts, and contents of one's heart) to others by using spoken language so that the intent can be understood by others [3]. By speaking, the intentions of the speaker will be understood by the listener.

Speaking is s'exprimer oralement, c'est transmettre des messages, généralement aux autres, en utilisant principalement la parole comme moyen de communication, that is, speaking is conveying messages to others, which basically uses language as a communication tool [4].Speaking skills referred to in this research development are students able to express their ideas, opinions, feelings to others verbally by using French in accordance with the context (related to the theme). Students are able to pronounce words or sentences correctly, vocabulary selection, use of grammar, fluency, and understanding of messages or information conveyed by the speaker to the interlocutor so that communication goals can be achieved.

Through the language learning process students are also expected to have the ability to communicate including discourse competence, namely the ability to understand and produce oral or written text that is realized in the four language skills namely listening (compréhension orale), speaking (production orale), reading (compréhension écrite), and writing (production écrite).

The Batak ethnic group as one of the tribes found in North Sumatra has a very thick cultural and kinship system. The Dalihan na tolu system as a pattern of Batak kinship has a value that is no less important than the other system that is well known today for the Indonesian nation and state, namely the Democracy system. The Batak kinship system places one's position with certainty from birth to death in 3 positions called dalihan na tolu. The word dalih can be translated as "furnace", meaning which, tolu means three which contain the same meaning, "3 important positions" in the kinship of the Batak people. Integrating the Batak culture of Dalihan na tolu in learning French speaking skills is one of the efforts to provide solutions to problems that might occur among students, to civilize them to give opinions politely and politely and to respect their friends when giving input or ideas, proposals, and opinions on a problem in order to find an agreed solution. On recent research on Mathematics learning models based on Batak culture-based problems (PBM-B3), developed through the learning model enables students to construct mathematical knowledge through problem solving that comes from facts and the Batak cultural environment, by applying Dalihan Na Tolu's social interaction patterns as learning strategies [5]. Research on improving French speaking ability using jeux aims to find out how to improve French speaking ability using jeux [6]. Jeux is one of the teaching techniques that can be used in teaching Expression Orale II courses. The results of the study showed that the use of Jeux can improve students' French speaking ability.

\section{Research Method}

Research on the development of blended learning models in the Production Orale course (speaking) French based on Batak local culture Dalihan NaTolu aims to improve French speaking competence in 5th semester students with the Plomp development model [7]. The learning model developed is a blended learning model combining face-to-face learning with online / offline learning that is designed using video media in the Youtube application. This learning delivery strategy is done with face-to-face learning $70 \%$ and online / offline learning 
$30 \%$, for learning purposes understanding and developing concepts are done online but for the purpose of learning in the form of skills that require learning to practice speaking processes, then the chosen form of learning is offline. The source of the research data were 20 students in the fifth semester of 2017 learning year at the FBS Unimed French Education Study Program who were taking the Production Orale level B1.

The learning design model was developed using the Plomp model through four phases, namely (1) Development Planning and Design, (2) Model Development using the Dalihan Na tolu syntax, (3) Expert Test, (4) Limited and extensive class trials [7].

Data collection techniques used is the initial test of speaking skills, expert test sheets, questionnaires and tests. The instrument used was an expert validation sheet, while for students used a questionnaire with closed and open answers, French speaking skills test equivalent to B1 was used to find out the improvement in learning outcomes.

Data analysis is done through validation and testing by calculating the score obtained to assess the quality of the learning model developed. The data collected in this study are in the form of qualitative data, namely a score with a scale of 1-5 (score 1 for very less, score 2 for less, score 3 for sufficient, score 4 for good, and score 5 for very good) for the initial assessment test instrument on student speaking competence. In the assessment of students' speaking skills used Échelle de Harris assessment (Évaluation de l'entretien dirigé) with components of prononciation (pronunciation), grammaire (grammar), vocabulaire (vocabulary), aisence (fluency), and comprehension, expert assessment and student assessment related to applied learning, strengths and weaknesses of learning [8]. Qualitative data scores are converted into quantitative data using a conversion reference using a Likert Scale. The results of the pretest and posttest were analyzed with comparative analysis which compares the results of the initial conditions with the conditions after learning with the model that has been developed.

\section{Results and Discussion}

\section{Findings}

The results of the study were obtained to answer the problem formulation related to the development process of learning model of production based on the Batak culture of na tolu, which was carried out through the investigation phase, the design phase, and the realization or construction phase as the first problem, while the test, evaluation, and revision phases will be carried out to answer second problem. Meanwhile, the third problem is to obtain a picture of improving student learning outcomes through speaking skills tests using CECR assessments equivalent to B1 DELF. Document analysis is carried out to complement and clarify the results of information, namely by observing, recording and collecting what is implied and written in each document or archive that is the source of the data. The process of developing a blended learning model in the learning of Production Orale (PO) level B1 DELF based on Batak culture in a fluctuant way is done gradually through problem analysis and needs analysis. There were 20 students in semester 5 in 2017 that were studied.

The process of developing a Blended learning model based on the Dalihan na Tolu Batak culture in learning to speak French is carried out through an investigation phase, a design phase, and a realization or construction phase.

The first meeting was to obtain preliminary data on French speaking ability level B1 DELF through an observation sheet containing an assessment of speaking skills related to 
pronunciation, grammar, vocabulary, fluency, and comprehension. In addition, to obtain data on student needs for the blended learning model, questions are given to $5^{\text {th }}$ semester students on speaking learning or Production Orale (PO) related to exprimer des opinions (expressing opinions). In this investigation phase, students are still left in a U-shaped sitting position, no grouping has been done. Furthermore, researchers asked questions related to exprimer des opinions to obtain information on how students express their opinions or ideas in French. Out of 20 students, 6 gave the right answer using the expression of moi, à mon avis, and je pense que. While 14 other students tend not to give responses, lack the courage to give answers, and lack of knowledge of other expressions that can be used to express opinions in French. The researcher then explains several other expressions that can be used to express opinions in French, for example quant à moi, moi personnellement, à mon point de vue, and je crois que.

After obtaining information at the investigation stage based on observations and observations about the knowledge and competence of 5th semester students in expressing opinions (exprimer des opinions) in speaking skills, then the students were given a topic with the theme Comment réussir à l'examen du DELF B1. Students are still in the original position, there is no group forming, each asked to give their opinions according to related themes. At this stage, $40 \%$ of students give answers using expressions that are better than before, but when students speak in French, there are still speaking mistakes that are not in accordance with the system of pronunciation and grammar of French as in conjugation of the verb. In addition, there are 7 to 8 students who are hesitant and halting in speaking so the ideas conveyed are unclear. Vocabulary selection is also an obstacle for students in expressing opinions. The results of observations and investigations conducted through video recording at the first meeting illustrate the condition that learning to speak French is more varied and can motivate students to improve their competence in learning French. Based on this first meeting, the results were obtained that there were 5 students who were smart and would be used as spokespersons in each group for the design of the second meeting in learning to speak French with a transitional system

The second meeting the students were introduced to a blended learning model that would be used in the learning process of speaking (PO) associated with the na tolu dadap system as one of the local cultures in North Sumatra. The researcher explains the mechanism in blended learning with na tolu's transitional system which is used as a PO learning model. In this learning model, students are grouped into three groups, namely the first group as the hula party, the second group as dongan tubu, and the third group as boru party, and the bere / ibebere group which is part of the boru party as illustrated below.

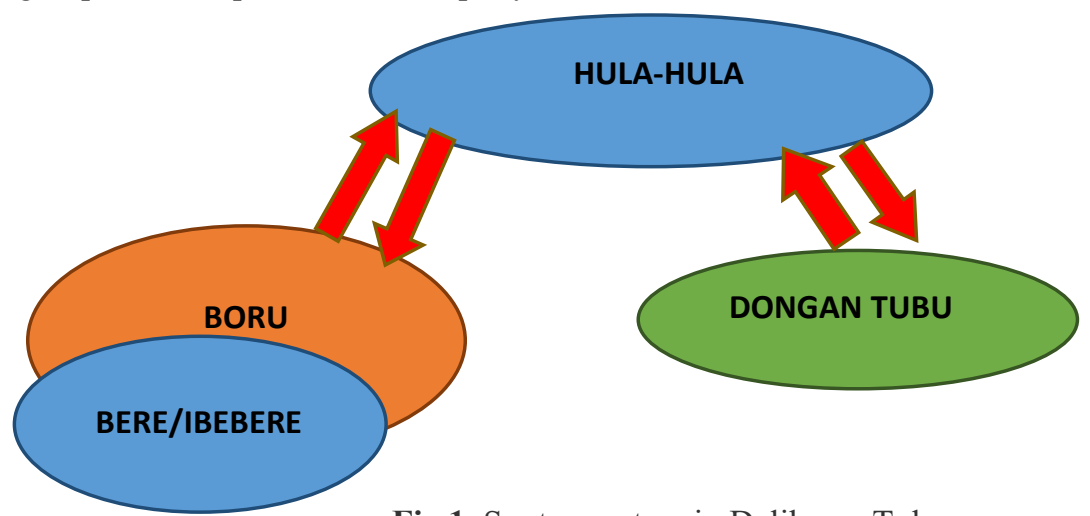

Fig 1. Syntax system in DalihannaTolu 
In the Dalihan na Tolu system model is used as one of the techniques in learning to speak. Students are divided into three groups for talking about Comment réussir à l'examen du DELF B1 to find a solution to a problem that arises in the group that must be discussed and decided through the results of the discussion according to mutual agreement by giving their respective opinions using the expression exprimer des opinions in French. Each party in the group is led by a competent spokesperson.

Among the three communities in the before-mentioned question, problems were raised by Dongan Tubu (6 students, 1 student as a spokesperson). However, those who are always given the opportunity to give an opinion at the beginning of a conversation in a discussion (dialogue) are boru parties (7 students, 1 as a spokesperson) and bere / ibebere (4 students). The results of opinions, suggestions, input from the boru party were further discussed by Dongan Tubu to obtain mutual agreement, and the last party to provide input and advice was hula (3 students, 1 as a spokesperson). As for the Boru party group played by students whose abilities are below average led by a spokesperson with abilities above average, and the Dongan Body is a student with moderate ability, led by a spokesperson whose abilities are also above average. Meanwhile, the hula is a group of students with above average competence, led by a competent spokesperson. This means that any discussion that requires broader insight, the hula-hula who will provide solutions to problems that arise to members of the group dongan tubu and boru and bere / ibebere groups.

Students who have been grouped into three communities namely hula-hula (3 people), dongan tubu (6 people) and boru and bere / ibebere (11 people) then engage in dialogue with fellow groups whose respective roles have been determined to express opinions to problems that arise in the group. Theme 1 about Comment réussir à l'examen $\mathrm{B} 1$ (how to succeed in the B1 exam) begins with the researcher's explanation of the situation that will be discussed in the student group in the discussion.

The dongan tubu group started talking about the B1 exam problem that would be faced in a few weeks, and the problem that arose was related to their preparations that were not yet available to deal with it so that the dongan tubu asked for their opinion first from the boru and bere / ibebere parties. Opinions, ideas, and proposals boru parties, bere / ibebere by using the expression of moi selon, à mon point de vue, moi personnellement, je pense que, etc., are conveyed to the body of Dongan who immediately discuss it again with their groups. In the group discussion, they also provide opinions, ideas, or proposals using expressions of how to express opinions, such as à mon opinion, quant à moi, à mon avis, etc. All opinions from boru, bere / ibebere and dongan tubu are then conveyed to the hula-hula. Various opinions, ideas or proposals conveyed by both parties dongan tubu and boru to the hula were remodeled again by the hula-hula, henceforth also given input and advice by the hula-hula to then be conveyed back to the other two parties so there is an agreement to accept the suggestions and ideas of the parties should be carried out by all parties.

Observations in the second meeting learning related to the theme Comment réussir l'examen B1 showed that students were competent to use expressions in exprimer des opinions, but there were still some errors in constructing sentences that were grammatically appropriate, for example in determining which modes were indicative, subjective, or conditionnel. In addition, difficulties are still seen when conjugating verbs to determine the time suitability between the present and passé periods. In addition, there are $60 \%$ of students who do not have a pronunciation in accordance with the French pronunciation system. At the third meeting, learning blended with the system of transitional na tolu with the theme Un cadeau de surprise pour l'anniversaire du prof (a surprise gift for a teacher's birthday). It is 
still the group of dongan tubu who started talks on the theme of birthday gifts which will be given as a surprise for a teacher. The problem that arises is what gifts will be given so that the body is asking for opinion from the boru and bere / ibebere parties. Some opinions, ideas, and proposals boru parties, bere / ibebere by using the expression of selon moi, à mon point de vue, moi personnellement, je pense que, etc., were conveyed to the body of dongan tubu who immediately discussed it again with his group. In dongan tubu group discussions, they also provide opinions, ideas, or proposals using expressions of how to express opinions whether they agree or disagree, such as je crois que, à mon opinion, à mon avis, etc. All opinions from boru, bere / ibebere and dongan tubu are then conveyed to the hula-hula. Various opinions, ideas or proposals conveyed by both parties dongan tubu and boru and bere/ ibebere to the hula-hula were refatted again by the hula-hula, henceforth also given input and suggestions by the hula-hula to then be conveyed back to the other two parties so there was an agreement to accept suggestions and ideas from the hula parties which further enriched the students' knowledge in this meeting by using the expressions of je suis d'avis que, je trouve que, d'après moi, je suis d'accord, etc.

The observations in the third meeting learning related to the Un cadeau de surprise pour l'anniversaire $d u$ prof theme showed that students were competent to use expressions in expressing des opinions, and were able to construct sentences that were grammatically appropriate, for example in determining which mode (mode) was indicative mode , subjectivity, or conditionnel. It appears that students have been more careful in determining the use of mode and time. Although there are still difficulties faced by students because of their inaccuracy or ignorance when using the word Si 'if' as a form of giving suggestions or invitations to something that must be followed by verbs when imparfait. At this meeting the students seemed more enthusiastic and motivated to express their ideas in the form of proposals, statements agreeing or not with the ideas put forward by the groups of boru and bere / ibebere, dongan tubu, and the hula-hula. In addition, when speaking, $80 \%$ of students have made improvements in their pronunciation, even students have been able to provide corrections to other students when listening to pronunciation that is incorrect, giving rise to different meanings, for example for the word vous [vu] 'you', spoken by students to be [fu] 'crazy'. After observation, the researcher gave an explanation related to the difficulties and errors of students in speaking skills (PO) of the blended learning model with a crossexamination system to be improved and further refined at the next meeting[9].

Observations in the fourth meeting learning related to the Passer le week-end ensemble theme show that $85 \%$ of students are competent to use expressions in exprimer des opinions, and are able to construct sentences that are grammatically appropriate, for example in determining which modes are indicative, subjective, or conditionnel. It appears that students have been more careful in determining the use of mode and time. Students are still enthusiastic and motivated to express their ideas in the form of proposals, statements agreeing or not with the ideas put forward by the groups of boru and bere / ibebere, dongan tubu, and the hulahula. After observation, the researcher gave an explanation related to the difficulties and errors of students in speaking skills (PO) of the blended learning model with a cross-examination system to be improved and further refined at the next meeting.

To obtain a blended learning model that can improve French language-based speaking skills (PO) based on local culture of the transitional system with a valid exprimer des opinions theme, the students' activity was showed on a video, validation (expert testing) with expertise in the field of academic education is qualified and has experience in research field. The validation questionnaire was given to the material validator as well as the French language validator, and the video validator which was a learning medium for speaking included three 
aspects namely aspects of media quality, aspects of language use, and aspects of media layout. Research on the development of a Blended learning model based on the Dalihan na Tolu Batak culture that has been developed is suitable for use in the learning process. This is because the learning model developed is a valid, practical and effective model[10]. Data obtained from material validation obtained a value of 3.3 with a valid category. In the validation of the language obtained an average value of 3.5 with a valid category. The validation of the learning model video obtained a value of 3.7 with a very valid category.

Local culture-based learning models that have been declared valid, then product trials are conducted. The product trial in the form of French speaking learning video B1 level themed Exprimer des opinions was conducted to obtain practicality data on a local culture-based learning model. The practicality of the model was obtained from the questionnaire data of student responses with closed answers ( 8 items) and open answers ( 1 item) with the following results: $98 \%$ felt new to the learning model presented, $100 \%$ were happy with the learning model of learning based on Batak culture with a system d transition na tolu, 100\% stated the learning model developed made it easier for students to understand the learning material, $98 \%$ were happy with the system of speaking learning models associated with blended learning, $100 \%$ could understand the mechanism in the local Batak culture-based learning model dadap na tolu, the learning model presented, the more motivating to learn to speak French, this learning model can improve learning achievement, be interested in local culture-based learning models, and be happy with the use of cross-cultural based learning models through video.

Open answer questions are asked about how the responses or impressions while learning to use local culture-based blended learning models in speaking skills, including the answers given are interesting learning models to increase interest in learning French, interesting and very easy to understand both by Batak tribe students itself or not the Batak tribe, it is very interesting because students are given the opportunity to evenly give opinions in French, a learning model that is exciting, impressed and more challenged to take part in speaking in French.

After the questionnaire data, student responses are collected and then analyzed. The results of the analysis become a benchmark or reference the level of practicality of the learning model developed. The level of practicality of local culture-based learning models obtained from student responses obtained a very practical category with an average score of $89.5 \%$ gain, pretest and post test results when learning with students' local culture-based blended learning models before and after using culture-based learning models The local Batak system is a transitional na tolu which is effective with an average student final grade of 80 in the Good category. The cognitive outcomes of students in speaking skills improved after using a local culture-based blended learning model.

\section{Conclusion}

Based on the results of the development of local culture-based blended learning Batak on a transitional system with the theme of exprimer des opinions that have been carried out, it can be concluded that: material validation obtained a value of 3.3 with a valid category. In the validation of the language obtained an average value of 3.5 with a valid category. Video learning model validation obtained a value of 3.7 with a very valid category. Local culturebased learning models that have been declared valid, then product trials are conducted. The 
product trial in the form of French speaking learning video B1 level themed Exprimer des opinions was conducted to obtain practicality data on a local culture-based learning model.

1) The development of a blended learning model based on local Batak culture is a transitional system that needs to be done using the Plomp development model

2) The validity level of local culture-based learning video Batak in the transitional system but the results of the material expert test are 3.3 with a valid category and the language expert test is 3.5 with a valid category, the results of the learning video design expert test are 3.7 with a very valid.

3) The level of practicality of local culture-based teaching materials obtained from student responses obtained a very practical category with an average score of $85 \%$. The level of effectiveness of the blended learning model was declared effective, with an average final grade of 80 in the Good category. The students' speaking competence increased in the system of pronunciation, grammar, fluency, and understanding after following the local culture-based learning model of Batak dalihan na tolu.

The Batak local culture-based blended learning model is effectively used in the learning process of speaking skills at level B1, it is hoped that French language teachers use it in three other linguistic competencies.

It is hoped that French KDBK lecturers can develop learning models in other sub-themes in the Réception Orale (Listening), Français de Tourisme (French Tourism) courses, and Production Écrite (Writing) courses[11].

\section{References}

[1] Supriyadi et.al. Pendidikan Bahasa Indonesia 2. Jakarta: Depdikbud. (2005).

[2] Sinaga, et.al. Implementasi Metode Ecriture Créative Berbasis Budaya Lokal untuk Meningkatkan Keterampilan Menulis Bahasa Perancis Level B1 DELF. Journal of Language and Literature. (2014).

[3] Discoll, M. Blended Learning: Let's Get Beyond the Hype. (2002).

[4] Sorez, H. Prendre la Parole. Hatier. Paris. (1995).

[5] Sinaga, Bornok, et.al. Pengembangan Model Pembelajaran Matematika Berdasarkan Masalah Berbasis Budaya Batak (PBM-B3). Jurnal Teknologi Pendidikan. (2014).

[6] Eviyanti, Evi. Peningkatan Kemampuan Berbicara Bahasa Prancis dengan Menggunakan Jeux. Journal: Language and Art. (2012).

[7] Plomp,Tj. Educational Design: Introduction from Trjeed Plomp; Niveen. Educational \& Training System. University of Twente. (1997).

[8] Tagliante, Christine. L'évaluation. Paris. CLE International. (1994).

[9] Conseil de l'Europe. Un Cadre Européen Commun de Référence Pour Les Langues: Apprendre, Enseigner, Évaluer. Paris. Les Éditions Didier. (2001).

[10] Gharbaoui, Omar. La Production Orale en FLE..Cas des étudiants de première année universitaire $\mathrm{Du}$ département des lettres et langue française Université de M'sila. Université de M'Sila Faculté des Lettres et des Langues Département des Lettres et Langue Française: Mémoire. (2014).

[11] Panggabean H.P. Pembinaan Nilai Adat Budaya Batak Dalihan Natolu. Dian Utama. Jakarta. (2007). 